\title{
Development of Emotional Skills through Interdisciplinary Practices Integrated into a University Curriculum
}

\author{
M. L. Pertegal-Felices, ${ }^{1}$ D. Marcos-Jorquera, ${ }^{2}$ R. Gilar-Corbí, ${ }^{1}$ and A. Jimeno-Morenilla ${ }^{2}$ \\ ${ }^{1}$ Developmental and Educational Psychology Department, University of Alicante, Alicante, Spain \\ ${ }^{2}$ Computer Technology and Computation Department, University of Alicante, Alicante, Spain \\ Correspondence should be addressed to M. L. Pertegal-Felices; ml.pertegal@ua.es
}

Received 5 April 2017; Accepted 17 July 2017; Published 28 August 2017

Academic Editor: Lieven Verschaffel

Copyright ( 2017 M. L. Pertegal-Felices et al. This is an open access article distributed under the Creative Commons Attribution License, which permits unrestricted use, distribution, and reproduction in any medium, provided the original work is properly cited.

\begin{abstract}
The emotional profile of university students has been related to both academic performance and professional success. Such evidence has led higher education professionals to ask whether students can be trained in emotional skills at university stage. However, learning specific emotional skills requires a considerable investment of time from students. This paper presents an intervention aimed at developing emotional skills through interdisciplinary teamwork, without adding specific courses that could decrease the time that students devote to their core studies. The results indicated that working in interdisciplinary teams improved the level of emotional skills without hindering the attainment of academic objectives.
\end{abstract}

\section{Introduction}

1.1. Emotional Skills and the Professional World. The business world has long been interested in the characteristics or abilities of professionals that improve a company's performance. In response to this interest, research on the skills of successful employees has been conducted. In their analyses of these skills, various authors [1-6] have concluded that general and emotional intelligence (EI) and personality factors are part of the complex network of skills required to successfully perform professional activities.

Researchers such as Caruso and Salovey [7] and Goleman [3] have theorized that EI contributes to the ability of individuals to work effectively in teams and manage work stress. EI can contribute to the quality of human relationships in the workplace because emotions have communicative and social functions: they pass on information regarding thoughts and intentions and help facilitate social encounters [8].

EI seems to not only help improve the working environment but also increase effectiveness at work. Numerous studies support the relationship between emotional skills and performance [9-15]. EI contributes to performance in the workplace, enabling individuals to establish and cultivate positive relationships, work effectively as part of a team, and build social capital $[3,7]$. Work performance often depends on support, advice, and other resources provided by third parties [16]. However, EI can also enhance performance by enabling individuals to independently manage their emotions to effectively address stress, perform efficiently under pressure, and adapt to organizational changes [17].

1.2. Emotional Skills and the Academic World. The scientific evidence presented in the previous section highlights the positive relationship between work and emotional skills. Given that the university setting represents the stage that precedes entrance into the world of work, scientists have wondered about the possible relationships between emotional skills and their influence in the university context.

Among the numerous studies that analyze the emotional profile of university students, those that relate this profile to academic performance [18-20], to gender [21, 22], to the development of the emotional skills required by companies [23, 24], or to burnout syndrome [25-27] stand out.

In addition, higher education professionals have asked if training students in this type of skill is possible during their time at university, given that one of the main objectives 
of universities is to promote employment and train highly efficient professionals to address the needs of society [28].

The Bologna Declaration [29], which summarizes approaches to the creation of a common European "space" of higher education before 2010, emphasized the importance of education (in terms of student acquisition of skills, abilities, competencies, and values) by adopting a new methodology oriented toward the learning of skills, including emotional skills. Similarly, the Tuning Educational Structures in Europe Project [28] develops professional profiles, learning outcomes, and skills that are desirable in terms of generic competencies related to each area of study. A number of these competencies are closely related to EI. In fact, they relate to individual capabilities with regard to expressing one's feelings and social skills, including interpersonal skills and the ability to work in teams.

1.3. Improving the Emotional Skills of University Students. Despite the large number of studies that analyze and support the importance of EI in university students, few interventions have focused on this kind of education. The reason may be that, despite several studies that have encouraged intervention [30-36], there has been reluctance to implement this approach. This may be because topics not directly related to the curriculum are difficult to introduce because of the pressure to enhance academic performance [37].

Basically, there are two types of interventions aimed at improving emotional skills: specific courses (or seminars) that are separate from other courses and interventions integrated into university teaching within existing courses.

It is clear that learning any subject requires time and effort on the part of students. Learning emotional skills also requires a considerable investment of time. Consequently, in a study of psychology students, Oberst et al. [38] proposed a series of seminars that were held in small groups and that focused on students. These seminars promoted emotional skills and EI through problem solving. The authors concluded not only that universities require radical structural changes if they are to include training in these skills but also that a significant amount of time should be devoted to this endeavor. The study by Bond and Manser [39] follows the same lines. In this study, the first semester in certain technology degree programs was modified to include a course on learning emotional skills. The course focused on five dimensions, of which self-consciousness was the only dimension that improved in the intervention group. The authors explain that the lack of improvement in the overall level of EI was the result of the course's short duration (15 weeks). In addition, students complained about the excessive amount of homework in relation to other courses.

EI intervention programs are often aimed at improving specific characteristics of university students. In fact, Short et al. [40] created a course in which coaching experts provided advice to psychology students to promote wellbeing, particularly during periods of increased academic stress. As a result of the lectures and seminars, the level of stress decreased in the studied groups, although the impact of the lectures and seminars on academic performance was not examined. Additionally, Yilmaz's research [41] focuses on the implementation of specific training for university students to improve anger control. An EI course demonstrated its effectiveness by significantly lowering anger levels among these students.

Shek et al. [42] designed a class at the University of Hong Kong titled "Tomorrow's Leader," which was based on the positive youth development approach. This class, which was included in the curriculum, promoted the intrapersonal abilities of students and proposed different evaluation systems. However, the impact of this class on the students' main study areas was not analyzed.

Dacre Pool and Qualter [43] analyzed an intervention at an English university for students from different disciplines. In this case, the intervention was designed as an optional 11week course for students in their second or third year. The intervention was considered successful because it improved the overall level of IE and emotional self-efficacy (ESE) of the students in the intervention group.

Numerous studies have proven the benefits of EI skills in university students. However, the few interventions that have proven effective in raising levels of EI have adversely affected students' academic performance by stealing time that they would otherwise have spent on subjects directly related to their studies. A recent study demonstrated that it is possible to improve the academic performance through an interdisciplinary approach [44]. This research will seek to intervene in EI via the core curriculum, that is, without using specific courses or seminars.

1.4. Assessing EI Skills. There are two types of EI models used to describe emotionally intelligent individuals-the Ability Model and mixed models-and various instruments are used to assess emotional intelligence. These instruments are associated with the various existing models for describing emotionally intelligent individuals.

According to the mixed models, EI is conceived as a trait, and, in order for an individual to behave in an emotionally intelligent manner, key personality traits are required $[4,30$, 45]. Based on these mixed models, various instruments that employ self-report measures have been developed. Among them, several stand out: the Bar-On Emotional Quotient Inventory (EQ-i) [46]; the Trait Emotional Intelligence Questionnaire (TEIQue), which resembles the EQ-i [47]; and the Emotional Competence Inventory (ECI) [3], which was designed to predict effectiveness and individual performance in the world of work and business.

The Ability Model views EI as a set of cognitive skills to adaptively use and manage emotions [5, 48, 49]. Different instruments (e.g., self-report and performance tests) have been developed to assess EI within the ability-based EI model, including the Trait Metamood Scale-48 (TMMS-48) developed by the Mayer-Salovey research group; the Spanish modified Trait Metamood Scale-24 (TMMS-24), which is Malaga research group's scaled-down, Spanish-language version of the TMMS-48 [50]; and the Schutte Self-Report Inventory (SSRI) by Schutte et al. [51]. All of these self-report measures have acceptable internal consistency, reliability, and 
validity. The Multifactor Emotional Intelligence Scale (MEIS) [52] and the Mayer-Salovey-Caruso Emotional Intelligence Test (MSCEIT) [53] also measure EI and employ a hands-on approach.

Self-report test measures base their reliability on the sincerity of the subject, that is, the way in which the subject perceives his or her behavior in the various personal situations proposed by the test. In individualized scenarios, for example, in a personal assessment by a sociologist or psychologist, the individual is interested in being objective, thus rendering this test reliability acceptable. However, doubts regarding reliability arise when the test is applied to groups of individuals, such as in a classroom or in certain social groups. The individual's experience of being evaluated alongside his or her peers may cause him or her, either consciously or unconsciously, to express his or her "ideal" personality rather than provide natural responses. In addition, certain selfreport measures overlap significantly with personality traits and lack a component based on ability or performance [54].

Performance tests, including the MSCEIT, evaluate EI using a series of objective and impersonal questions. The tests evaluate the ability to perceive, use, understand, and regulate emotions. Based on typical daily scenarios, such tests measure how well individuals perform certain tasks and solve emotional problems rather than requiring them to provide a subjective perception of their emotional skills. In fact, performance tests have a low correlation with selfreport tests (Bracket, Salovey, 2006) and a minimal overlap with personality trait measures (Bracket, Mayer, 2003).

1.5. Research Hypothesis and Objectives. The present study examines whether interdisciplinary teamwork may also have a positive influence on the level of emotional skills of students who share a common project but who have different goals.

Our initial hypothesis is that working in interdisciplinary teams can improve emotional skills without the need to create specific courses that could negatively affect the time students devote to their studies.

In particular, we propose a curricular adaptation within the methodology of two compulsory courses in two degree programs. This approach enables students to experiment with working in interdisciplinary teams, as they would in professional environments, but to do so in this case within the university. Specifically, we propose the design of a guide to interdisciplinary practices. The curricular adaptation was introduced into the Usability and Accessibility course in the Multimedia Engineering degree program and into the Developmental Psychology course in the Primary School Teaching degree program. The research objectives include improving student emotional abilities, as measured by performance tests, without affecting syllabi content and thus not altering the specific content of each course or affecting student academic performance.

\section{Method}

2.1. Academic Context. The Multimedia Engineering degree program merges traditional engineering and computer engineering. Its general objective is to train professionals in the
TABLE 1: Enrolled students.

\begin{tabular}{lcccc}
\hline & Students & Female & Male & Age \\
\hline Usability and Accessibility & 47 & $8(17 \%)$ & $39(83 \%)$ & 20.8 \\
Developmental Training & 64 & $39(61 \%)$ & $25(39 \%)$ & 19.7 \\
Total & 111 & 47 & 64 & \\
\hline
\end{tabular}

ICT sector who will be capable of directing new multimedia projects in both the leisure and digital entertainment spheres and managing content for dissemination in information networks.

The Usability and Accessibility (UA) course of this Spanish University is a required first-semester course in the first year of the Multimedia Engineering degree program that has been taught since the 2010/2011 academic year. The course's main objective is to provide students with the necessary concepts and tools to design and develop multimedia products with usability features that make using and learning these projects easier and accessibility features that allow users to access them whatever their status, ability, or situation.

The UA students' task in this work focused on the multimedia aspects of creating the application interface, particularly emphasizing the activity's ease of use and learning (usability) and ensuring access to end users (accessibility). During product development, it was emphasized that the product users would be children between six and 12 years of age, a fact that would notably affect the type of interface used.

The main objective of the Primary School Teaching degree program is to train teachers in primary education to perform efficiently in different contexts; to adapt to social, cultural, scientific, technological, and educational changes; and to fully understand the various primary school subjects and their interdisciplinary relationship while becoming critical thinkers with initiative who are committed to their profession and who are capable of reflecting on their teaching practice.

The Developmental Psychology (DP) course of this Spanish University is part of the Learning and Personality Development module. The course is part of the basic training provided in this degree program and is taught during the first four months of the first year. The course establishes the groundwork that students require to understand the characteristics of their own pupils and to optimize pupil development and the teaching-learning process.

2.2. Participants. Students who were enrolled in the Usability and Accessibility and Developmental Psychology courses participated in this study.

The total sample of students consisted of 111 individuals: 43 students in the experimental group and 68 in the control group. Table 1 summarizes the distributions of the students in both courses, indicating the number of enrolled students, their gender distribution, and their average age.

2.3. Instruments. Given the advantages of performance measurement methods compared with self-report tests in the educational context of this study, the MSCEIT Ability Model measure has been chosen as the tool to evaluate EI. 


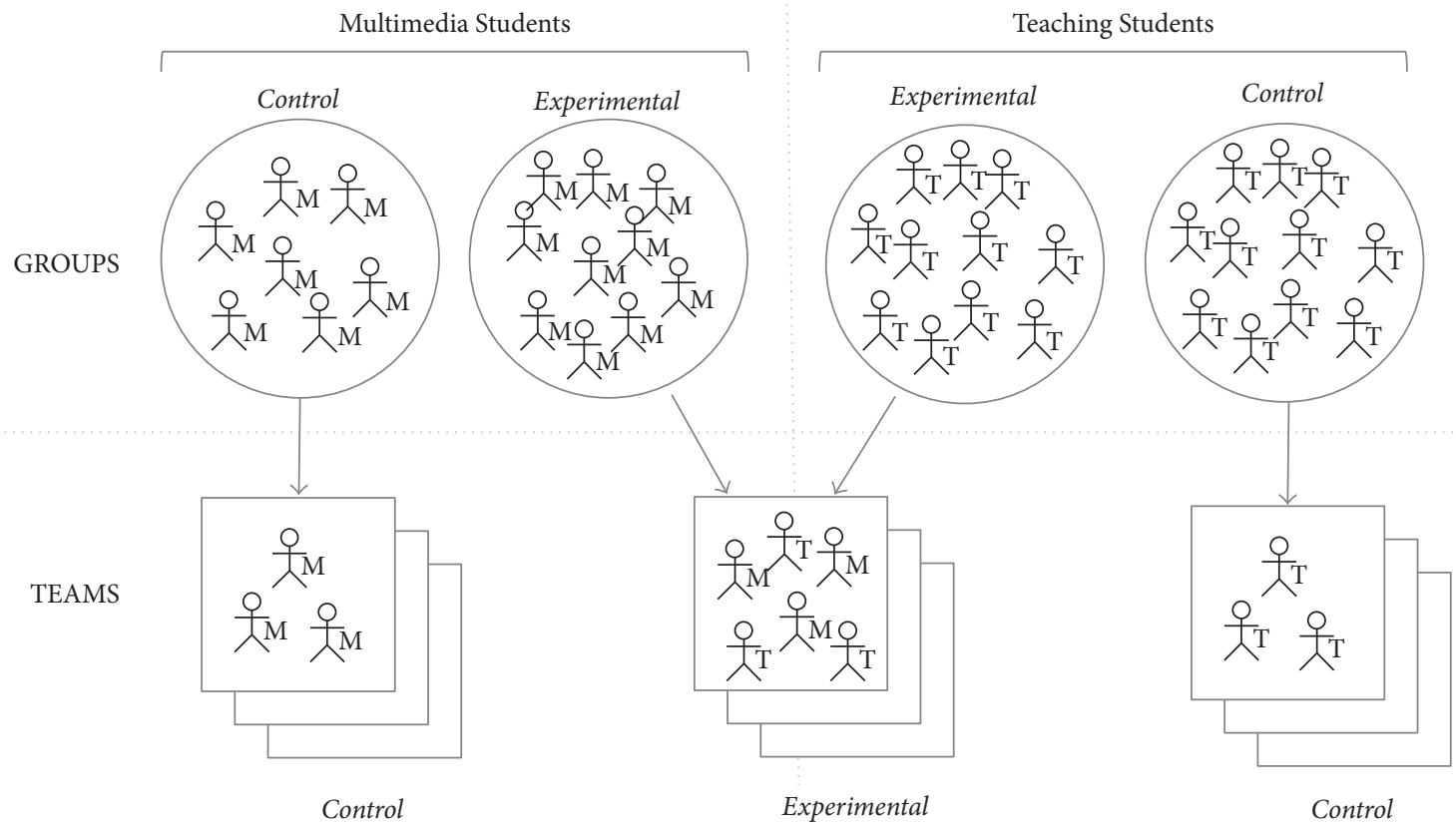

FIGURE 1: Distribution process for groups and teams.

The MSCEIT (i.e., the Spanish version adapted by Extremera and Fernández-Berrocal [55]) evaluates EI through a series of objective and impersonal questions. It tests the respondent's ability to perceive, use, understand, and regulate emotions (Perceiving Emotions, Facilitating Thought, Understanding Emotions, and Managing Emotions). The MSCEIT demonstrates good internal consistency, with 0.95 total reliability, oscillating between 0.93 and 0.76 across subscales [56].

In addition, this test has adequate factorial, construct, and predictive validity with moderately adequate psychometric properties [53, 57]. It also demonstrates discriminant validity with other analytical intelligence measures and various personality constructs while better interacting with interpersonal relationships [58]. Similarly, once the relevant cognitive and personality variables are controlled for, this instrument demonstrates evidence of incremental validity for academic performance [59].

The test evaluates four factors: the ability to perceive (PEIQ), the ability to use (FEIQ), the ability to understand (UEIQ), and the ability to manage (MEIQ) emotions.

2.4. Procedure. The main goal of the interdisciplinary proposal is the creation of Web-based multimedia activities that stimulate cognitive skills in primary school children (from six to 12 years of age). For evaluation purposes, the university students were randomly divided into two groups: an experimental group of students who created the products through collaborations of multimedia and teaching students in interdisciplinary teams and a control group of students who created the same products in monodisciplinary teams without contact with students from other degree programs
TABLE 2: Student distribution in groups and teams.

\begin{tabular}{lcccc}
\hline & \multicolumn{2}{c}{ Experimental group } & \multicolumn{2}{c}{ Control group } \\
& Students & Teams & Students & Teams \\
\hline Usability and Accessibility & 23 & 9 & 24 & 8 \\
Developmental Training & 20 & & 44 & 9 \\
Total & 43 & 9 & 68 & 17 \\
\hline
\end{tabular}

(see Figure 1). The student distribution among the groups and teams is summarized in Table 2. The learning goals, assessments, and materials were the same for both groups.

The research study was conducted during the first semester of the academic year. The experimental group for the interdisciplinary experiment was selected from a course section whose schedule coincided with both the Usability and Accessibility and Developmental Psychology training courses-that is, when the students from both courses were available on the same day and at the same time.

The Web-based activities were organized and documented on the basis of school year and aptitude developed. Specifically, each team had to design and develop eight activities, two from each course level: infant, first, second and third years. The requirements of each activity were determined by the children's course level and were designed to improve their cognitive development. At the end, the teams had to report performance data and the time taken to complete the task for each activity to support professionals in assessing the children's progress.

The experimental teams of teaching and multimedia students were intended to have similar characteristics to those of interdisciplinary teams found in actual working environments. The goal of the multimedia students was to develop a 
TABLE 3: Schedule for joint interdisciplinary course sessions.

\begin{tabular}{|c|c|c|c|}
\hline Week & Activity & UA sessions & DP sessions \\
\hline \multicolumn{4}{|l|}{1} \\
\hline 2 & \multirow{5}{*}{ Previous activities } & \multirow{4}{*}{$\begin{array}{l}\text { 1st-5th sessions: development of } \\
\text { low complexity web product }\end{array}$} & 1st session \\
\hline 3 & & & 2nd session \\
\hline 4 & & & 3rd session \\
\hline 5 & & & 4th session \\
\hline 6 & & $\begin{array}{l}\text { 6th session: submission of first } \\
\text { web product }\end{array}$ & 5th session \\
\hline 7 & \multirow{7}{*}{$\begin{array}{l}\text { Web-based activity for } \\
\text { primary school children }\end{array}$} & $\begin{array}{l}\text { 7th session: developing } \\
\text { application requirements }\end{array}$ & $\begin{array}{l}\text { 6th session: } \\
\text { application request }\end{array}$ \\
\hline 8 & & 8th session & 7th session \\
\hline 9 & & $\begin{array}{l}\text { 9th session: submission of } \\
\text { application specifications }\end{array}$ & $\begin{array}{l}\text { 8th session: } \\
\text { submission of } \\
\text { materials and } \\
\text { specifications }\end{array}$ \\
\hline 10 & & 10th session & 9th session \\
\hline 11 & & $\begin{array}{l}\text { 11th session: design submission } \\
\text { (sketch) }\end{array}$ & $\begin{array}{l}\text { 10th session: } \\
\text { content review and } \\
\text { modifications }\end{array}$ \\
\hline $12-14$ & & 12th-14th sessions & 11th-14th sessions \\
\hline 15 & & $\begin{array}{l}\text { 15th session: submission of the } \\
\text { final product, presentation, and } \\
\text { assessment }\end{array}$ & $\begin{array}{l}\text { 14th session: } \\
\text { submission and } \\
\text { assessment of the } \\
\text { website }\end{array}$ \\
\hline 16 & & & 15th session \\
\hline
\end{tabular}

Web-based multimedia product with a Web interface focused on facilitating the product's use and learning (i.e., usability) while ensuring access to end users (i.e., accessibility). The goal of the teaching students was to design and develop activities to stimulate the cognitive skills of children in preschool and primary school, including attention, memory, or reasoning. To ensure effective collaboration between the teaching and multimedia students, faculty incorporated small exercises to overcome any barriers. Both the control and experimental groups carried out the same work.

One of the most important aspects of implementing the interdisciplinary sessions was to plan the session calendars of both courses to allow for four joint practical sessions. Both courses had 15 sessions in the semester, but the DP course started in the second week. The joint practical sessions were held in weeks 7, 9, 11, and 15 . In addition, each team, whether interdisciplinary or monodisciplinary, was permitted to organize as many working meetings as necessary to complete the project. Table 3 gives the schedule for the interdisciplinary sessions.

During their first sessions of the semester, the students developed other activities of low complexity that were unrelated to the product to be developed in the joint sessions. This initial development activity gave the students the basic skills necessary to successfully cope with the development of the Web-based activity.

To ensure suitable development of the practical activities and adherence to the planned schedule, a set of actions were put in place for coordination among team members-both intrateam (students belonging to the same course) and interteam (students of both courses). Within each team (in both the experimental and control groups), a student acted in the role of general coordinator. For the experimental group, due the different schedules of the multimedia and teaching students, in each interdisciplinary group one UA student and one DP student took the role of communication manager with the other course. The interdisciplinary teams met during the joint class sessions. The interactions among the students in the interdisciplinary teams are shown in Figure 2; the size of the dots represents the level of responsibility of each student.

EI was measured on the first day of class by administering the test during class time. The test administration required approximately $30-45$ minutes.

Once the training sessions during which the students in both groups performed the projects were completed, EI was again measured using the MSCEIT.

The content and specific skills evaluation was conducted using an objective performance test of the participants. This test was created following the basic procedure in the construction of criterion-referenced tests [60-62] and consisted of 30 items. These items consisted of 30 sentences with four response options. The participants were required to select the correct option. The total score on the test was established by the well-known formula $P=A-E /(n-1)$, which penalizes mistakes made while completing a test. 


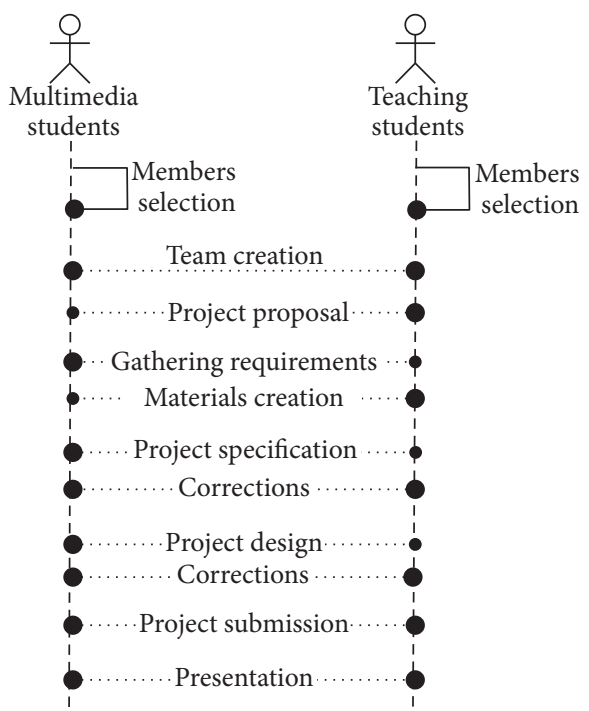

FIGURE 2: Coordination stages for interdisciplinary teams.

2.5. Design and Data Analysis. A nonequivalent control group design [63] with pre- and posttest control groups was used to test the research hypothesis.

The statistical analysis was conducted using the GLM (General Linear Model) module of the statistical software package SPSS version 21.0. A multivariate analysis of variance (MANOVA) and a univariate analysis of variance (ANOVA) of repeated measures were performed. In this factorial analysis of variance, at least one factor is based on independent observations, and at least one of these factors is based on correlated observations [64].

Additionally, interaction graphs were created to represent the differences observed between the experimental and control groups in the pre- and posttest situations and to observe the direction of the differences.

Finally, a comparison of averages was conducted to determine whether there were significant differences in the performances of the experimental and control groups.

\section{Results}

The two groups that underwent different interventions were compared. Thus, the independent variable or factor was membership in one group or another (i.e., the type of intervention), and the criterion or dependent variables were the scores achieved by the subjects in the EI test.

First, prior to the intervention, the differences in EI as measured by the MSCEIT between the two groups were evaluated. To this end, the means for the independent samples were compared. The results indicate that there were no significant differences in any of the variables studied between the two groups in the pretest phase ( $p=124$ (PEIQ); $p=$ 0.502 (FEIQ); $p=0.054$ (UEIQ); $p=0.129$ (MEIQ)).

In the analysis of sample normality, it was found that the sampling populations were not normally distributed. However, the single factor variance analysis used in this case is robust with respect to violations of this assumption [65].
This outcome means that if the assumption is violated, Type I or Type II errors are not significantly affected [64].

Box's $M$ test was used, obtaining homogeneity of the variance-covariance matrices only for the FEIQ factor ( $p=$ 0.298 ) and no homogeneity of the variance-covariance matrices for the remaining factors $(p=0.000)$. However, because of contrast sensitivity to the lack of normality, other procedures could be used to analyze the homogeneity of the variance-covariance matrices, including the Levene test. This test yielded values of significance for three of the four analyzed variables that were less than 0.05 . Therefore, it can be stated that contrast is not satisfied. However, as Tabachnick and Fidell [66] observe, the larger ratio of variance between groups must not exceed $10: 1$. In this case, the ratio is $1: 3.70$, which means that the violation of this assumption has a minimal impact.

The repeated-measures general linear model was used to assess treatment effectiveness in the development of EI in the sample. The dependent variables were defined by the four factors evaluated by the MSCEIT: perception of emotions (PEIQ), use of emotions (FEIQ), understanding of emotions (UEIQ), and management of emotions (MEIQ). The intrasubject factors were represented by the evaluation time (pre- and posttest) for each of the dependent variables. The intersubject factors depended on the presence or absence of treatment (i.e., the experimental or the control group).

In the analysis of the intersubject effect tests, the observed values indicate that the average of all observations differs from zero $(0<p<0.016)$ in all of the cases and that the intersubject factor effect on the dependent variables was significant for PEIQ and UEIQ measures $(0<p<0.031)$.

Figures 3-6 present interaction graphs that indicate the direction of the differences.

The tests of the intrasubject effects (Tables 4-7) indicate that, in the case of PEIQ and MEIQ (Tables 4 and 7), only the effect of the interaction between the two independent variables (time of assessment and implementation of the program) is significant. In the case of FEIQ and UEIQ (Tables 5 and 6), time of evaluation and time of interaction are significant.

Regarding observed power (i.e., the correct rejection of the null hypothesis of mean equality), the interaction effect of the variables for time of assessment $*$ program implementation is greater than that of the time of assessment separately in PEIQ, UEIQ, and MEIQ. The power for time of assessment separately in FEIQ is still greater.

In Table 8, the means, standard deviations, and effect sizes for all of the pre- and posttest variables are reported.

The effect size $\left(\mathrm{eta}^{2}\right)$, the proportion of total variability attributable to a factor [64], and the difference between one time and another [67] that result from the interaction between the time of assessment and the implementation of the program were small for all four dependent variables (ranging between 0.46 and 0.75 ).

In order to analyze the possible impact of a control variable, a linear regression of Post-Pre scores on grades was performed. The results show that the contribution of grades was not significant in explaining any of the four variables related to EI. 
TABLE 4: PEIQ intrasubject and intersubject effects.

\begin{tabular}{|c|c|c|c|c|c|c|c|}
\hline Intrasubject effect & & $\begin{array}{l}\text { Type III } \\
\text { sum of } \\
\text { squares }\end{array}$ & $\mathrm{df}$ & $F$ & Sig. & eta $^{2}$ & $\begin{array}{l}\text { Observed } \\
\text { Power }^{\mathrm{a}}\end{array}$ \\
\hline \multirow{4}{*}{ PEIQ } & Sphericity assumed & 149627,797 & 1 & 2,878 & ,093 & ,026 & 390 \\
\hline & $\begin{array}{l}\text { Greenhouse- } \\
\text { Geisser }\end{array}$ & 149627,797 & 1,000 & 2,878 & ,093 &, 026 & ,390 \\
\hline & Huynh-Feldt & 149627,797 & 1,000 & 2,878 & 093 & ,026 & 390 \\
\hline & Lower-bound & 149627,797 & 1,000 & 2,878 & ,093 & ,026 & ,390 \\
\hline \multirow{4}{*}{ PEIQ * group } & Sphericity assumed & 279048,067 & 1 & 5,367 & ,022 & ,047 & ,632 \\
\hline & $\begin{array}{l}\text { Greenhouse- } \\
\text { Geisser }\end{array}$ & 279048,067 & 1,000 & 5,367 & ,022 & ,047 & ,632 \\
\hline & Huynh-Feldt & 279048,067 & 1,000 & 5,367 & ,022 & ,047 & ,632 \\
\hline & Lower-bound & 279048,067 & 1,000 & 5,367 &, 022 &, 047 & ,632 \\
\hline \multirow{4}{*}{ Error (factor 1) } & Sphericity assumed & 5667455,888 & 109 & & & & \\
\hline & $\begin{array}{l}\text { Greenhouse- } \\
\text { Geisser }\end{array}$ & 5667455,888 & 109,000 & & & & \\
\hline & Huynh-Feldt & 5667455,888 & 109,000 & & & & \\
\hline & Lower-bound & 5667455,888 & 109,000 & & & & \\
\hline \multicolumn{8}{|l|}{ Intersubject effect } \\
\hline Intersection & & 326967,206 & 1 & 6,809 & ,10 & 059 &, 734 \\
\hline Group & & 236090,071 & 1 & 4,917 &, 029 & ,043 &, 594 \\
\hline Error & & 5234131,776 & 109 & & & & \\
\hline
\end{tabular}

${ }^{\mathrm{a} C o m p u t e d ~ u s i n g ~ a l p h a ~}=.05$.

TABLE 5: FEIQ intrasubject and intersubject effects.

\begin{tabular}{|c|c|c|c|c|c|c|c|}
\hline Effect & & $\begin{array}{l}\text { Type III } \\
\text { sum of } \\
\text { squares }\end{array}$ & $\mathrm{df}$ & $F$ & Sig. & eta $^{2}$ & $\begin{array}{l}\text { Observed } \\
\text { power }^{\mathrm{a}}\end{array}$ \\
\hline \multirow{4}{*}{ FEIQ } & Sphericity assumed & 1297,819 & 1 & 14,669 &, 000 &, 119 & ,967 \\
\hline & $\begin{array}{l}\text { Greenhouse- } \\
\text { Geisser }\end{array}$ & 1297,819 & 1,000 & 14,669 &, 000 & ,119 & ,967 \\
\hline & Huynh-Feldt & 1297,819 & 1,000 & 14,669 & ,000 & ,119 & ,967 \\
\hline & Lower-bound & 1297,819 & 1,000 & 14,669 &, 000 & ,119 & ,967 \\
\hline \multirow{4}{*}{ FEIQ $*$ group } & Sphericity assumed & 462,612 & 1 & 5,229 & ,024 & ,046 & ,620 \\
\hline & $\begin{array}{l}\text { Greenhouse- } \\
\text { Geisser }\end{array}$ & 462,612 & 1,000 & 5,229 &, 024 & ,046 & ,620 \\
\hline & Huynh-Feldt & 462,612 & 1,000 & 5,229 &, 024 & ,046 & 620 \\
\hline & Lower-bound & 462,612 & 1,000 & 5,229 & ,024 & ,046 & ,620 \\
\hline \multirow{4}{*}{ Error (factor 1) } & Sphericity assumed & 9643,316 & 109 & & & & \\
\hline & $\begin{array}{l}\text { Greenhouse- } \\
\text { Geisser }\end{array}$ & 9643,316 & 109,000 & & & & \\
\hline & Huynh-Feldt & 9643,316 & 109,000 & & & & \\
\hline & Lower-bound & 9643,316 & 109,000 & & & & \\
\hline \multicolumn{8}{|c|}{ Intersubject effect } \\
\hline Intersection & & 2114192,873 & 1 & 8236,571 &, 000 & ,987 & 1,000 \\
\hline Group & & 451,467 & 1 & 1,759 & ,188 & ,016 &, 260 \\
\hline Error & & 27978,515 & 109 & & & & \\
\hline
\end{tabular}

${ }^{\mathrm{a} C o m p u t e d ~ u s i n g ~ a l p h a ~}=.05$. 
TABLE 6: UEIQ intrasubject and intersubject effects.

\begin{tabular}{|c|c|c|c|c|c|c|c|}
\hline Effect & & $\begin{array}{l}\text { Type III } \\
\text { sum of } \\
\text { squares }\end{array}$ & $\mathrm{df}$ & $F$ & Sig. & eta $^{2}$ & $\begin{array}{c}\text { Observed } \\
\text { power }^{\mathrm{a}}\end{array}$ \\
\hline & $\begin{array}{l}\text { Sphericity } \\
\text { assumed }\end{array}$ & 194288,379 & 1 & 7,746 & ,006 &, 066 & ,788 \\
\hline \multirow[t]{4}{*}{ UEIQ } & $\begin{array}{c}\text { Greenhouse- } \\
\text { Geisser }\end{array}$ & 194288,379 & 1,000 & 7,746 & ,006 &, 066 & ,788 \\
\hline & Huynh-Feldt & 194288,379 & 1,000 & 7,746 & ,006 & ,066 & ,788 \\
\hline & Lower-bound & 194288,379 & 1,000 & 7,746 &, 006 &, 066 & ,788 \\
\hline & $\begin{array}{l}\text { Sphericity } \\
\text { assumed }\end{array}$ & 222233,388 & 1 & 8,860 & ,004 &, 075 & ,839 \\
\hline \multirow[t]{4}{*}{ UEIQ * group } & $\begin{array}{l}\text { Greenhouse- } \\
\text { Geisser }\end{array}$ & 222233,388 & 1,000 & 8,860 & ,004 & ,075 & 839 \\
\hline & Huynh-Feldt & 222233,388 & 1,000 & 8,860 &, 004 & ,075 & ,839 \\
\hline & Lower-bound & 222233,388 & 1,000 & 8,860 & ,004 &, 075 &, 839 \\
\hline & $\begin{array}{l}\text { Sphericity } \\
\text { assumed }\end{array}$ & 2734100,567 & 109 & & & & \\
\hline \multirow[t]{3}{*}{ Error (factor 1) } & $\begin{array}{c}\text { Greenhouse- } \\
\text { Geisser }\end{array}$ & 2734100,567 & 109,000 & & & & \\
\hline & Huynh-Feldt & 2734100,567 & 109,000 & & & & \\
\hline & Lower-bound & 2734100,567 & 109,000 & & & & \\
\hline \multicolumn{8}{|c|}{ Intersubject effect } \\
\hline Intersection & & 944917,611 & 1 & 39,136 &, 000 & ,264 & 1,000 \\
\hline Group & & 229928,746 & 1 & 9,523 & ,003 &, 080 &, 864 \\
\hline Error & & 2631766,074 & 109 & & & & \\
\hline
\end{tabular}

${ }^{\mathrm{a}}$ Computed using alpha $=.05$.

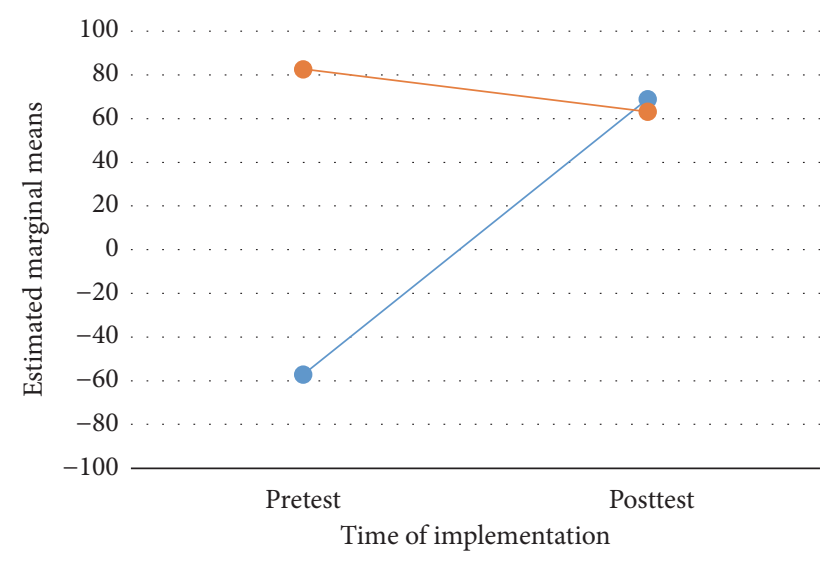

GROUP

- Experimental

- Control

FIGURE 3: Graph of interactions for PEIQ.

Finally, a mean comparison using an independent samples $t$-test to determine if there are significant differences in the performance of the experimental and control groups was conducted. The results indicate that the values of the averages of both groups are equal $(p=0.659)$.

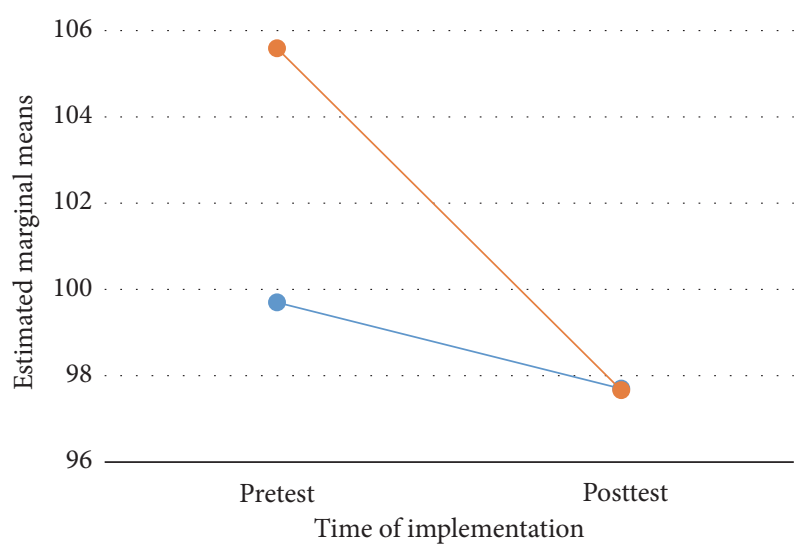

GROUP

- Experimental

Control

FIgURE 4: Graph of interactions for FEIQ.

\section{Discussion and Conclusions}

The results confirm the main hypothesis of this study: working in interdisciplinary teams improves the level of emotional skills. This intervention shows that it is possible to improve the EI skills of both multimedia engineering and primary 
TABLE 7: MEIQ intrasubject and intersubject effects.

\begin{tabular}{|c|c|c|c|c|c|c|c|}
\hline Effect & & $\begin{array}{l}\text { Type III } \\
\text { sum of } \\
\text { squares }\end{array}$ & df & $F$ & Sig. & eta $^{2}$ & $\begin{array}{c}\text { Observed } \\
\text { power }^{\mathrm{a}}\end{array}$ \\
\hline & $\begin{array}{l}\text { Sphericity } \\
\text { assumed }\end{array}$ & 157651,511 & 1 & 3,053 & ,083 & ,027 & ,410 \\
\hline \multirow[t]{4}{*}{ MEIQ } & $\begin{array}{l}\text { Greenhouse- } \\
\text { Geisser }\end{array}$ & 157651,511 & 1,000 & 3,053 & ,083 & ,027 & ,410 \\
\hline & Huynh-Feldt & 157651,511 & 1,000 & 3,053 & 083 & ,027 & ,410 \\
\hline & Lower-bound & 157651,511 & 1,000 & 3,053 & ,083 &, 027 & ,410 \\
\hline & $\begin{array}{l}\text { Sphericity } \\
\text { assumed }\end{array}$ & 272199,691 & 1 & 5,271 & ,024 & ,046 & ,624 \\
\hline \multirow[t]{4}{*}{ MEIQ * group } & $\begin{array}{l}\text { Greenhouse- } \\
\text { Geisser }\end{array}$ & 272199,691 & 1,000 & 5,271 & ,024 & ,046 & ,624 \\
\hline & Huynh-Feldt & 272199,691 & 1,000 & 5,271 &, 024 & ,046 & ,624 \\
\hline & Lower-bound & 272199,691 & 1,000 & 5,271 & ,024 & ,046 & ,624 \\
\hline & $\begin{array}{l}\text { Sphericity } \\
\text { assumed }\end{array}$ & 5628399,174 & 109 & & & & \\
\hline \multirow[t]{3}{*}{ Error (factor 1) } & $\begin{array}{l}\text { Greenhouse- } \\
\text { Geisser }\end{array}$ & 5628399,174 & 109,000 & & & & \\
\hline & Huynh-Feldt & 5628399,174 & 109,000 & & & & \\
\hline & Lower-bound & 5628399,174 & 109,000 & & & & \\
\hline \multicolumn{8}{|c|}{ Intersubject effect } \\
\hline Intersection & & 288533,334 & 1 & 6,030 & ,16 & ,052 & ,682 \\
\hline Group & & 227425,226 & 1 & 4,753 & ,31 & ,042 &, 580 \\
\hline Error & & 5215800,594 & 109 & & & & \\
\hline
\end{tabular}

${ }^{\mathrm{a}}$ Computed using alpha $=.05$.

TABLE 8: Means, standard deviations, and effect sizes for all variables.

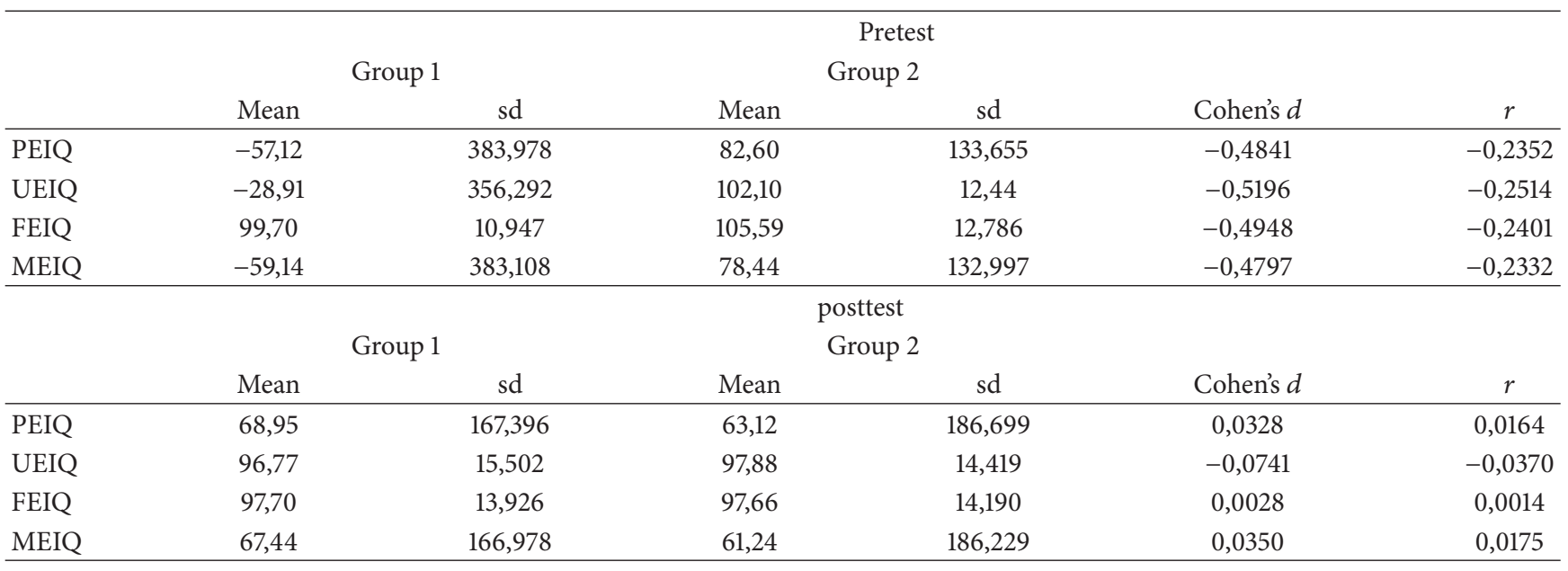

education teacher program students through a program of interdisciplinary practical activities that overlap with other courses in the curriculum. This training program simulates a professional environment in the classroom that benefits students.

The participants in the control and experimental groups presented the same levels of emotional skills at baseline.
However, the participants in the experimental group, who completed the interdisciplinary training program, demonstrated significant improvement in two of the measured socioemotional skills: emotional perception and emotional management. Therefore, we can state that those subjects who worked with the interdisciplinary method succeeded in improving their ability to recognize and identify emotions 


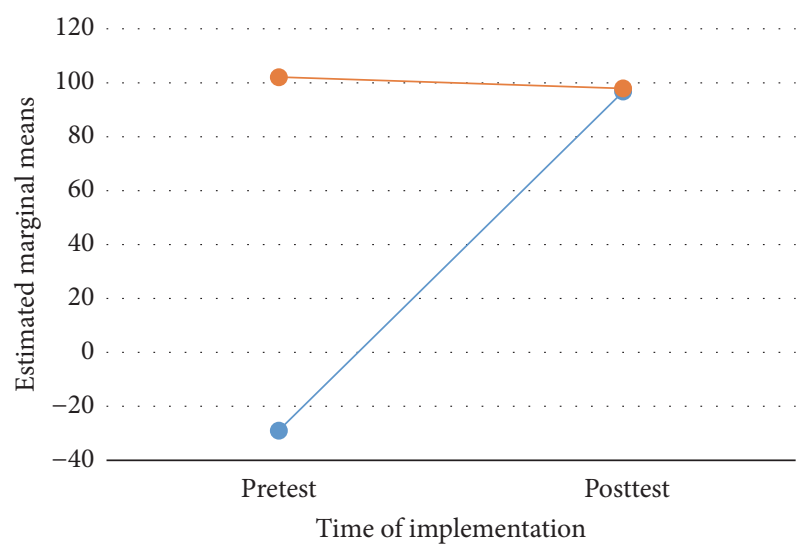

$$
\begin{aligned}
& \text { GROUP } \\
& - \text { Experimental } \\
& - \text { Control }
\end{aligned}
$$

FIgURE 5: Graph of interactions for UEIQ.

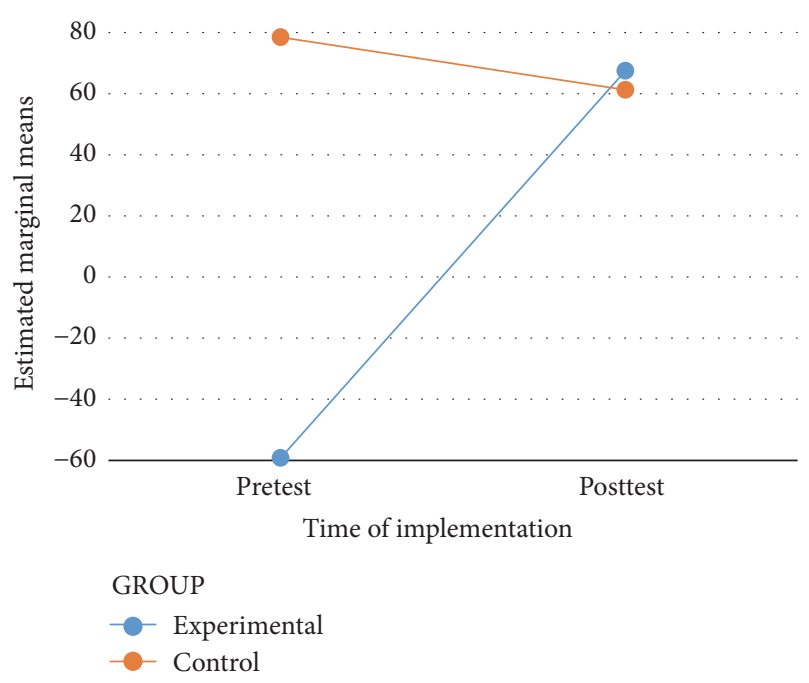

FIGURE 6: Graph of interactions for MEIQ.

in others and in the world around them and improved their ability to effectively use their own feelings while combining emotion and thinking to exhibit effective behaviors.

It is important to note that, with this interdisciplinary method, the proposed academic objectives continue to be met because, as we observed, there were no differences in the final performances of the students, regardless of the group to which they belonged. Consequently, we can assert that the use of this method benefits the development of the skills necessary in life and the work world without impeding the acquisition of other curricular content.

Educators who integrate this interdisciplinary activity in similar programs will find that it is easier to implement and that it has the advantage of not overloading students with extracurricular courses that enhance teamwork but take time from their training in specific competencies.

It is necessary to develop curricular designs that include the integration of interdisciplinary perspectives that provide opportunities for students to think about the strengths and limitations of their disciplines. It is important to consider the value of other disciplinary perspectives, prepare students to work effectively in teams, and provide students with the requisite ability to integrate in the job market where there is a variety of disciplinary areas.

4.1. Study Limitations. Given the nature of this intervention, we can infer that its application would be easier in universities with a substantial variety of degree programs and student types, which would result in team synergy and a wide array of communication nuances that could positively influence the emotional capacities of interdisciplinary groups. A suggestion for overcoming the difficulty of scheduling different faculties would be to establish multidisciplinary teams within a degree field; the teams would be similar to those commonly used in Australian universities-for example, in final-year capstone projects across different disciplines.

However, one of the main difficulties confronted by this program was the coordination of courses across different degree programs. To conduct the joint training sessions, a rearrangement of schedules among programs and departments was required. In this way, the interdisciplinary groups were able to share class time, thereby avoiding coordination issues among students.

Another difficulty was related to the type of project to conduct. The project had to include specific aspects of both degree programs. Therefore, the project was divided into small modules in an attempt to include the maximum possible knowledge from each subject area.

4.2. Future Research. Future research will aim at extending this intervention to other courses and degree programs at this university. The first objective is to find a group of students in a degree program that can participate in interdisciplinary courses throughout their university careers. In this way, a longitudinal study may be performed to analyze the evolution of students' emotional skills. In a second phase, student employability should be analyzed to determine if the program also has a positive effect on the incorporation of graduates into the world of work.

In this work, only EI traits have been measured. The authors' suspicion is that possible impact on the behavioral level could be much stronger. In order to measure this impact, future studies will include other instruments as ESCI [68], which would be proposed and contrasted with MSCEIT.

\section{Conflicts of Interest}

The authors declare that there are no conflicts of interest regarding the publication of this paper.

\section{Acknowledgments}

This work was funded by the Ministry of Economy and Competitiveness of Spain (Ministerio de Economía y Competitividad de España), through Reference EDU2015-64562R Project, and the University of Alicante through Reference GRE14-16. 


\section{References}

[1] R. E. Boyatzis, D. Goleman, and K. Rhee, "Clustering competente in emotional intelligence: insights from the emotional competence inventory (ECI)," in Handbook of Emotional Intelligence, R. Bar-On and J. D. A. Parker, Eds., pp. 343-362, JosseyBass, San Francisco, Calif, USA, 2000.

[2] D. Goleman, Emotional Intelligence, Bantam Books, New York, NY, USA, 1995.

[3] D. Goleman, Working with Emotional Intelligence, Bantam Books, Nueva York, 1998.

[4] D. Goleman, "An eI-based theory of performance," in The Emotionally Intelligent Workplace, C. Cherniss and D. Goleman, Eds., pp. 27-44, Jossey-Bass, San Francisco, 2001.

[5] J. D. Mayer and P. Salovey, "What is emotional intelligence?" in Emotional Development and Emotional Intelligence: Educational Applications, P. Salovey and D. Sluyter, Eds., pp. 3-31, Basic Books, Nueva York, 1997.

[6] P. Salovey and J. Mayer, "Emotional intelligence," Imagination, Cognition and Personality, vol. 9, no. 3, pp. 185-211, 1990.

[7] D. R. Caruso and P. Salovey, The Emotionally Intelligent Manager, Jossey-Bass, San Francisco, Calif, USA, 2004.

[8] D. Keltner and J. Haidt, "Social functions of emotions," in Emotions: Current Issues and Future Directions, T. J. Mayne and G. A. Bonanno, Eds., pp. 192-213, Guilford, New York, NY, USA, 2001.

[9] R. E. Boyatzis, "Using tipping points of emotional intelligence and cognitive competences to predict financial performance of leaders," Psicothema, vol. 18, no. 1, pp. 124-131, 2006.

[10] R. E. Boyatzis, "Competencies in the 21st century," Journal of Management Development, vol. 27, no. 1, pp. 5-12, 2008.

[11] C. M. Brotheridge and R. T. Lee, "The emotions of managing: an introduction to the special issue," Journal of Managerial Psychology, vol. 23, no. 2, pp. 108-117, 2008.

[12] R. K. Cooper, "Applying emotional intelligence in the workplace," Training and Development, vol. 51, no. 12, pp. 31-39, 1997.

[13] C. R. Dreyfus, "Identifying competencies that predict effectiveness of RyD managers," Journal of Management Development, vol. 27, no. 1, pp. 76-91, 2008.

[14] E. S. Koman and S. B. Wolff, "Emotional intelligence competencies in the team and team leader: a multi-level examination of the impact of emotional intelligence on team performance," Journal of Management Development, vol. 27, no. 1, pp. 55-75, 2008.

[15] J. Murga and E. Ortego, "La importancia de la inteligencia emocional en el funcionamiento de las organizaciones," Encuentros en Psicología Social, vol. 1, no. 4, pp. 79-82, 2003.

[16] S. E. Seibert, M. L. Kraimer, and R. C. Liden, "A social capital theory of career success," Academy of Management Journal, vol. 44, no. 2, pp. 219-237, 2001.

[17] P. N. Lopes, S. Côté, D. Grewal, J. Kadis, M. Gall, and P. Salovey, "Emotional intelligence and positive work outcomes," Psicothema, vol. 18, pp. 132-138, 2006.

[18] M. A. Adell, Estrategias Para Mejorar El Rendimiento Académico De Los Adolescentes, Pirámide, Madrid, 2006.

[19] E. R. Navarro, "El rendimiento académico: concepto, investigación y desarrollo," REICE. Revista Iberoamericana sobre Calidad, Eficacia y Cambio en Educación, vol. 1, no. 2, 2003.

[20] J. D. Parker, L. J. Summerfeldt, M. J. Hogan, and S. A. Majeski, "Emotional intelligence and academia success: examining the transition from high school to university," Personality and Individual Differences, vol. 36, no. 1, pp. 163-172, 2004.
[21] P. Fernández-Berrocal and D. Ruiz, "La inteligencia emocional en la educación," Revista Electrónica de Investigación Psicoeducativa, vol. 15, no. 6, pp. 421-436, 2008.

[22] K. V. Petrides and A. Furnham, "Gender differences in measured and self-estimated trait emotional intelligence," Sex Roles, vol. 42, no. 5-6, pp. 449-461, 2000.

[23] D. Molero and A. Reina-Estévez, "Competencias socioemocionales y actitud para la empleabilidad en desempleadas universitarias," Revista Española de Orientación y Psicopedagogía, vol. 23, no. 2, pp. 92-104, 2012.

[24] M. L. Pertegal-Felices, J. L. Castejón-Costa, and A. JimenoMorenilla, "Differences between the personal, social and emotional profiles of teaching and computer engineering professionals and students," Studies in Higher Education, vol. 39, no. 7, pp. 1185-1201, 2014.

[25] N. Extremera and A. Durán, "Inteligencia emocional y su relación con los niveles de burnout, engagement y estrés en estudiantes universitarios," Revista de Educación, vol. 342, pp. 239-256, 2007.

[26] G. F. Sewell, "Como la inteligencia emocional puede influir positivamente," Military Review, 2011.

[27] M. Weinstein, The relationship between emotional intelligence and burnout among postgraduate university students [MSC thesis], University of Johannesburg, 2011.

[28] J. González and R. Wagenaar, Tuning Educational Structures in Europe II, University of Deusto and University of Groningen, Bilbao (España), 2006.

[29] Ministers of Education of the European Union, "The joint declaration about the european higher education area," in Proceedings of the Bologna Convention of 19th of June 1999, Bologna, Italy, 1999.

[30] R. Bar-On, "Emotional and social intelligence: insights from the emotional quotient inventory (EQ-i)," in Handbook of Emotional Intelligence, R. Bar-On and J. D. A. Parker, Eds., Jossey-Bass, San Francisco, Calif, USA, 2000.

[31] C. E. Domitrovich, R. C. Cortes, and M. T. Greenberg, "Improving young children's social and emotional competence: a randomized trial of the preschool "PATHS" curriculum," Journal of Primary Prevention, vol. 28, no. 2, pp. 67-91, 2007.

[32] M. J. Elias and J. Clabby, Building Social Problem Solving Skills: Guidelines from a School-Based Program, Jossey-Bass, San Francisco, Calif, USA, 1992.

[33] M. J. Elias, M. Gara, M. Ubriaco, P. A. Rothbaum, J. F. Clabby, and T. Schuyler, "Impact of a preventive social problem solving intervention on children's coping with middleschool stressors," American Journal of Community Psychology, vol. 14, no. 3, pp. 259-275, 1986.

[34] M. T. Greenberg, C. A. Kusche, E. T. Cook, and J. P. Quamma, "Promoting emotional competence in school-aged children: the effects of the PATHS curriculum," Development and Psychopathology, vol. 7, no. 1, pp. 117-136, 1995.

[35] G. R. Low and D. B. Nelson, Emotional Intelligence and College Success: A Researchbased Assessment and Intervention Model, Center for Education Development and Evaluation Research (CEDER), Kingsville, TX, USA, 2006.

[36] D. Nelis, J. Quoidbach, M. Mikolajczak, and M. Hansenne, "Increasing emotional intelligence: (how) is it possible?" Personality and Individual Differences, vol. 47, no. 1, pp. 36-41, 2009.

[37] M. Zeidner, R. D. Roberts, and G. Matthews, "Can emotional intelligence be schooled: a critical review," Educational Psychologist, vol. 37, no. 4, pp. 215-231, 2002. 
[38] U. Oberst, J. Gallifa, N. Farriols, and A. Vilaregut, “Training emotional and social competences in higher education: the seminar methodology," Higher Education in Europe, vol. 34, no. 3-4, pp. 523-533, 2009.

[39] B. Bond and R. Manser, Emotional Intelligence Interventions to Increase StudentSuccess, Higher Education Quality Council of Ontario, Toronto, 2009.

[40] E. Short, G. Kinman, and S. Baker, "Evaluating the impact of a peer coaching intervention on well-being amongst psychology undergraduate students," International Coaching Psychology Review, vol. 5, no. 1, pp. 27-35, 2010.

[41] M. Yilmaz, "The effects of an emotional intelligence skills training program on the consistent anger levels of turkish university students," Social Behavior and Personality, vol. 37, no. 4, pp. 565-576, 2009.

[42] D. T. Shek, R. C. Sun, Y. H. Chui et al., "Development and evaluation of a positive youth development course for university students in Hong Kong," The Scientific World Journal, vol. 2012, Article ID 263731, pp. 1-8, 2012.

[43] L. Dacre Pool and P. Qualter, "Improving emotional intelligence and emotional self-efficacy through a teaching intervention for university students," Learning and Individual Differences, vol. 22, no. 3, pp. 306-312, 2012.

[44] D. Marcos-Jorquera, M. L. Pertegal-Felices, A. JimenoMorenilla, and R. Gilar-Corbí, "An interdisciplinary practical for multimedia engineering students," IEEE Transactions on Education, vol. 60, no. 1, pp. 8-15, 2017.

[45] C. Cherniss, "Emotional intelligence: what it is and why it matters," in Proceedings of the Ensayopresentadoen el Annual Meeting of the Society for Industrial and Organizational Psychology, Rugters University, Nueva Orleans, 2000.

[46] R. Bar-On, EQ-i Bar-On Emotional Quotient Inventory: A measure of emotional inventory [PHD thesis], Multi-Health Systems, Canada, 1997.

[47] A. Furnham and K. V. Petrides, "Trait emotional intelligence: behavioural validation in two studies of emotion, recognition and reactivity to mood induction," European Journal of Personality, vol. 17, no. 1, pp. 39-57, 2003.

[48] J. D. Mayer, D. R. Caruso, and P. Salovey, Mayer-Salovey-Caruso Emotional Intelligence Test (MSCEIT): User's Manual, MHS Publisher, Toronto, Canada, 2002.

[49] J. D. Mayer, P. Salovey, and D. Caruso, "Models of emotional intelligence," in Handbook of Intelligence, J. R. Sternberg, Ed., pp. 396-420, Cambridge, Nueva York, 2nd edition, 2000.

[50] P. Fernández-Berrocal, N. Extremera, and N. Ramos, "Validity and reliability of the Spanish modified version of the traid metamood scale," Psychological Reports, vol. 94, no. 3, pp. 751-755, 2004.

[51] N. S. Schutte, J. M. Malouff, L. E. Hall et al., "Development and validation of a measure of emotional intelligence," Personality and Individual Differences, vol. 25, no. 2, pp. 167-177, 1998.

[52] J. D. Mayer, D. R. Caruso, and P. Salovey, "Emotional intelligence meets traditional standards for an intelligence," Intelligence, vol. 27, no. 4, pp. 267-298, 1999.

[53] J. D. Mayer, P. Salovey, and D. R. Caruso, Mayer-SaloveyCaruso Emotional Intelligence Test (MSCEIT). Item Booklet, MHS Publisher, Toronto, Canada, 2002.

[54] F. Romanelli, J. Cain, and K. M. Smith, "Emotional intelligence as a predictor of academic and/or profesional success," American Journal of Pharmaceutical Education, vol. 70, no. 3, article 69, 2006.
[55] N. Extremera and P. Fernández-Berrocal, Cuestionario MSCEIT (Versión española 2.0.) de Mayer, Salovey y Caruso, Multi-Health Systems, Toronto, Canada, 2002.

[56] N. Extremere, P. Fernández-Berrocal, and P. Salovey, "Spanish version of the mayer-salovey-caruso emotional intelligence test (MSCEIT). version 2.0: reliabilities, age and gender differences," Psicothema, vol. 18, no. 1, pp. 42-48, 2006.

[57] J. D. Mayer, P. Salovey, D. R. Caruso, and G. Sitarenios, "Measuring emotional intelligence with the MSCEIT v2.0," Emotion, vol. 3, no. 1, pp. 97-105, 2003.

[58] P. N. Lopes, P. Salovey, and R. Straus, "Emotional intelligence, personality, and the perceived quality of social relationships," Personality and Individual Differences, vol. 35, no. 3, pp. 641-658, 2003.

[59] K. A. Barchard, Does Emotional Intelligence Assist in The Prediction of Academic Success? [PHD thesis], University of British Columbia, Vancouver, B.C. Canada, 2000.

[60] J. L. Castejón, L. Navas, G. Sampascual, and M. Griñán, "Evaluación de los aprendizajes en el área de Ciencias Sociales, Geografía e Historia de la Educación Secundaria Obligatoria," Ediciones Club Universitario, Alicante, Spain, 1999.

[61] W. Popham, Criterion Referenced Measured, Prentice Hall, Englewood Cliffs, NJ, USA, 1978.

[62] F. Rivas, El Proceso de Enseñanza-Aprendizaje en la Situación Educativa, Ariel, Barcelona, 1997.

[63] D. T. Campbell and J. C. Stanley, Experimental and QuasiExperimental Designs for Research, Ravenio Books, 2015.

[64] H. Gardner, “Three distinct meanings of intelligence," in Models of Intelligence: International Perspectives, R. J. Sternberg, Ed., pp. 43-54, APA, Washingtong, Wash, USA.

[65] G. V. Glass, P. D. Peckham, and J. R. Sanders, "Consequences of failure to meet assumptions underlying fixed effects analyses of variance and covariance," Review of Educational Research, vol. 42, no. 3, pp. 237-288, 1972.

[66] B. Tabachnick and L. Fidell, Using Multivariate Statistics, Allyn and Bacon, Boston, MA, USA, 5th edition, 2007.

[67] R. Ledesma, G. Macbeth, and N. Cortada De Kohan, “Tamaño del efecto: revisión teórica y aplicaciones con el sistema estadístico viSta," Revista Latinoamericana de Psicología, vol. 40, no. 3, pp. 425-439, 2008.

[68] R. E. Boyatzis, "Commentary on ackley (2016): updates on the ESCI as the behavioral level of emotional intelligence," Consulting Psychology Journal: Practice and Research, vol. 68, no. 4, pp. 287-293, 2016. 


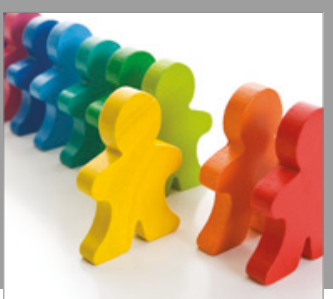

Autism

Research and Treatment
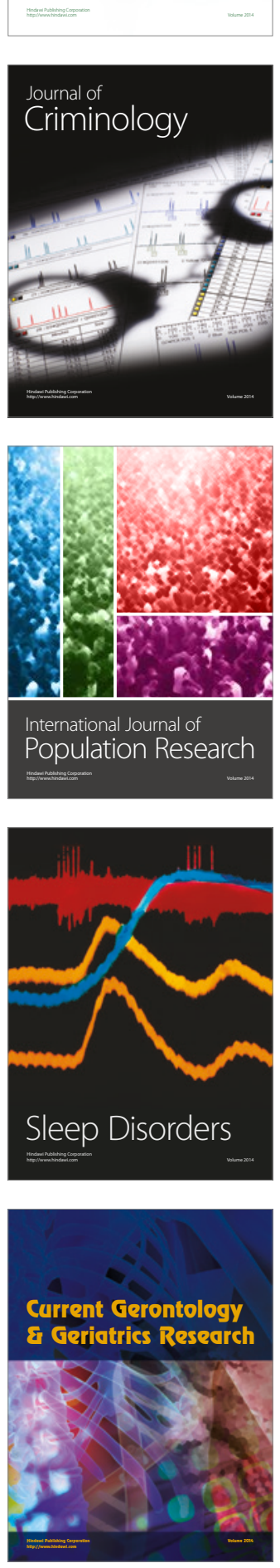

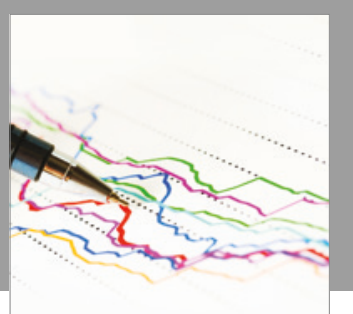

Economics

Research International

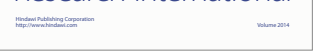

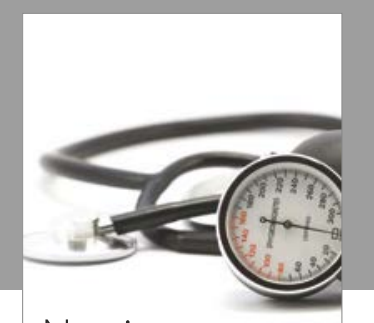

Nursing

Research and Practice

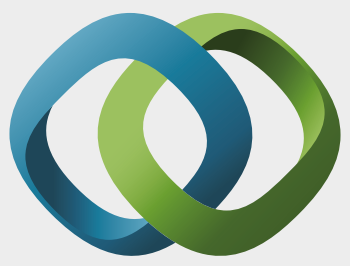

\section{Hindawi}

Submit your manuscripts at

https://www.hindawi.com
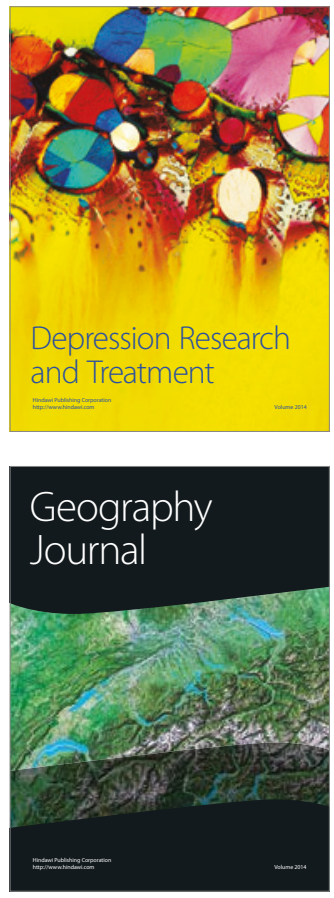
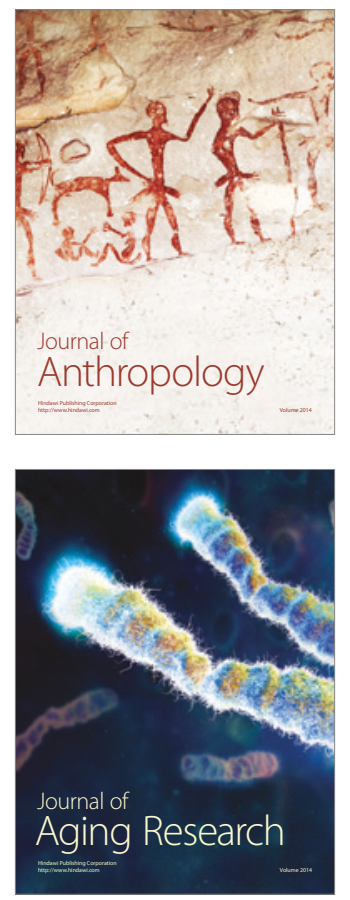
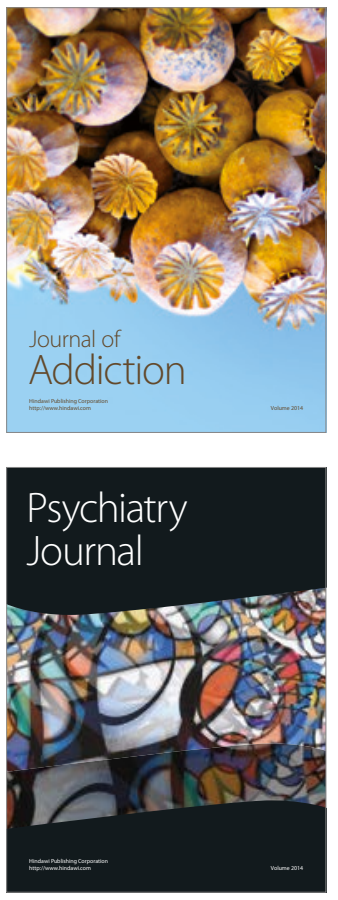

Child Development

Research

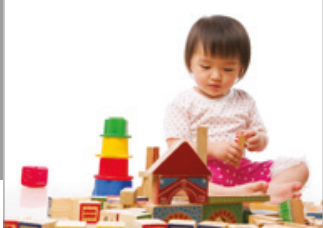

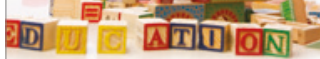
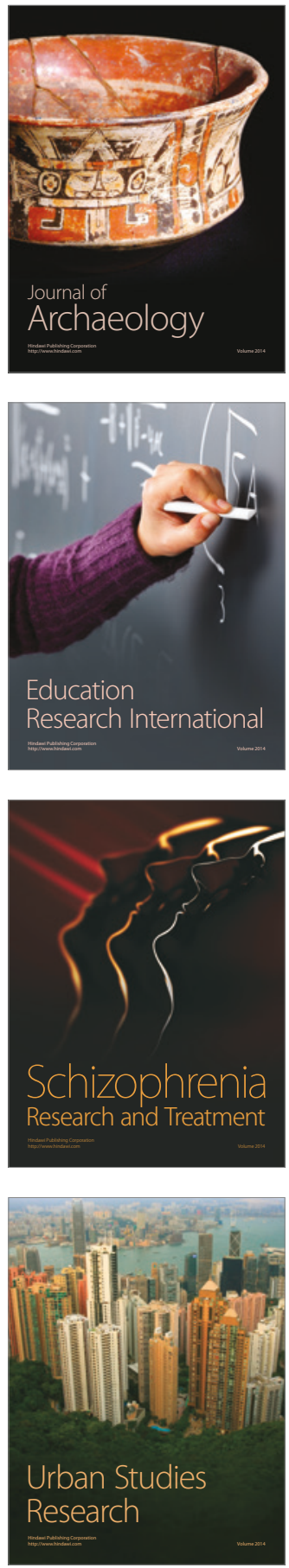